\title{
THE GENETICS OF GONOPODIAL POLYMORPHISM IN TWO SPECIES OF POECILIID FISH
}

\author{
KLAUS D. KALLMAN and RICHARD BOROWSKY \\ Genetics Loborotory, Osborn Loborotories of Morine Sciences, \\ New York Zoologicol Society, Brooklyn, New York 11224 \\ Deportment of Biology, New York University Heights, \\ Bronx, New York 10453
}

Received 23.viii.71

\section{INTRODUCTION}

Natural populations of several species of Xiphophorus are known to be highly polymorphic for a variety of colour patterns that affect different parts of the body and fins (Kallman and Atz, 1966). Most of the patterns with the exception of the tailspot series are known to be under the control of sex-linked loci. The sex-determining mechanism of $X$. variatus and $X$. milleri is of the $\mathrm{XX}$ 우-XY $\mathrm{X} \delta$ type, but in $X$. maculatus females of the same natural population may be either WY, WX or XX and males XY or XY (Kallman 1965a, 1970). The gonosomes of the three species are homologous (Kallman and Atz, 1966). The sex-determining mechanisms of the remaining five species of Xiphophorus are not well understood. The black macromelanophore patterns are in general equally strongly expressed in males and females, but some of the red patterns are poorly developed in females or not at all (Kallman, 1970). Least known is a polymorphism of $X$. maculatus, $X$. variatus variatus, $X$. v. xiphidium and $X$. milleri that affects the coloration of the gonopodium, the male copulatory organ. Although the study of Xiphophorus began in the late 1920's the only references to such a pattern are found in Gordon (1931), Miller and Minckley (1963) and Rosen and Kallman (1969). Some males of all four forms have a gonopodium that appears conspicuously black from a distance and contrasts sharply with the dull olivaceous grey coloration of the body. Apparently this pattern has no counterpart in the unmodified anal fin of the female. The transformation of the anal fin into a gonopodium is under the control of androgenic hormone (Grobstein, 1948). The structure of the gonopodium and its use during courtship and mating has been discussed in detail by Clark, Aronson and Gordon (1954), Franck (1964), Gordon and Rosen (1951) and Rosen and Gordon (1953).

We should like to call this component of polymorphism (and also others of Xiphophorus, see Kallman, 1970) to the attention of ethologists in the hope that they may determine whether one or the other colour variant possesses a selective advantage during courtship or agonistic behaviour. The present report describes the inheritance of black gonopodium $(\mathrm{Gn})$ in $X$. milleri and X. v. variatus.

\section{Material AND Methods}

The stock of $X$. milleri (GL) listed in table 1 was derived from fish collected in Lake Catemaco, Veracruz, Mexico, in 1963. Male 1543-11 (table 2) was received in December 1963 through the courtesy of Dr R. R. Miller, 
University of Michigan. He obtained his stock of $X$. milleri from Dr R. L. Dressler, who collected the fish in Lake Catemaco earlier that year. Two preserved collections of $X$. milleri have been examined (University of Michigan Museum of Zoology\#177310, 184556).

The variable platyfish, Xiphophorus variatus variatus, listed in table 7 were collected at a number of locations in the Rio Tamesi drainage (Rios Sabinas, Guayalejo and Boquilla) in east-central Mexico. Female 2111-2 was captured at the Nacimiento of Rio Sabinas (Arroyo La Flor) and 2109-1 was obtained from the Arroyo Sarco, a small tributary to the Arroyo Encino that flows into the Rio Sabinas about $6 \mathrm{~km}$. from its source. Fish of pedigree 2113 and 2115 came from two similar arroyos $3 \mathrm{~km}$. north of the village of Encino. Fish of pedigree 2116 were caught in the Rio Guayalejo at Jaumave. All of the above fish were collected in February 1967. The VT stock is of mixed origin. It has been derived from fish obtained in 1957 at an unknown location in the Rio Tamesi drainage; the descendants were subsequently hybridised with individuals collected in 1965 in the Rio Boquilla. Most of these locations have been described in some detail by Borowsky (1969) and Darnell (1962).

Pigment patterns besides Gn referred to in this paper are Sv (spottedventral) of $X$. milleri and $\mathrm{P}^{1}$ and $\mathrm{P}^{2}$ (punctatus) of $X$. v. variatus. The three patterns are caused by macromelanophores and are sex-linked (Kallman and Atz, 1966). For details concerning gonopodial structure the reader is referred to the papers by Gordon and Rosen (1951) and Rosen and Gordon (1953).

Maintenance of fish has been described previously (Kallman, 1965a), but since the growth rate of $\mathrm{Gn}$ and non-Gn fish in $X$. milleri has been examined (see tables 5 and 6 below), it is important to go into some detail. Matings are set up in 15-litre aquaria. If the size of the brood is in excess of 12 young, the fry are spread out into similar tanks, but never more than 10-12 fish together. At 6 weeks $X$. milleri in our laboratory begin to differentiate sexually and the sexes can be told apart by the differently shaped anal fins. In males it is smaller and more triangular, but the third, fourth and fifth anal fin rays (referred to as the 3-5 complex) have not yet begun to elongate. At this time males and females are separated and recombined but again never more than 12 fish are kept together. After sexual maturation has been attained males of successive broods may be combined in 28-litre tanks. This is the reason why some sibs may grow up together from the time (6 weeks) that sexual differentiation commences, although they were raised in different aquaria during some of the first 6 weeks. Males of $X$. milleri may be sexually mature (capable of siring offspring) at the age of $2 \frac{1}{2}$ months. At the age of 6 weeks Sv and Gn fish cannot be told apart.

The standard lengths of the fish were measured with vernier calipers with the aid of a low-power dissecting microscope to insure consistent placement of the calipers. The expression of $\mathrm{Gn}$ is variable. Fishes in a group were ranked by successive visual comparison with respect to the degree of gonopodial pigmentation. When the degree of pigmentation of two fishes was too close for a distinction to be made, tied ranks were assigned.

\section{Results}

The CL stock of $X$. milleri has been bred in the Genetics Laboratory for 15 generations comprising 22 crosses of the type + 우 $\times \mathrm{Sv}$ ô. all but two 
were brother-to-sister matings. With few exceptions $\mathrm{Sv}$ is inherited by males only (table 1) suggesting Y-linkage (Kallman, 1965b; Kallman and Atz, 1966). The 10 Sv females represent either cross-overs between the $X$ and $\mathrm{Y}$ chromosomes or exceptional females with the sex chromosome constitution XY. Such XY females are also known from X. maculatus, Poecilia reticulata and Oryzias latipes (for references, see Kallman, 1968). The genotypes of the two Sv females tested were XY (see below). None of the fish listed in table 1 developed a black gonopodium.

TABLE 1

Inheritance of $S v$ in the $C L$ stock of Xiphophorus milleri

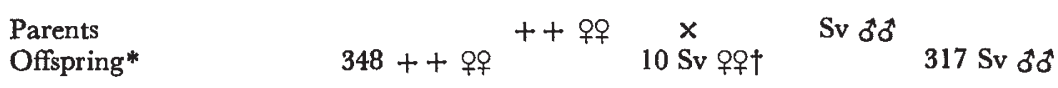

* Summary of 15 generations involving 22 crosses.

$\uparrow 1 \mathrm{~Sv}$ ㅇ each, 4th, 12th and 13th generation; $7 \mathrm{~Sv}$ 우 6 th generation.

The data represented in table 2 are consistent only with the assumption that $\mathrm{Gn}$ is $\mathrm{Y}$-linked and shows incomplete penetrance. Most relevant are pedigrees 1784 and 1983 through 2357 which represent essentially backcrosses of $\mathrm{Gn}$ males to the CL stock without $\mathrm{Gn}$. If $\mathrm{Gn}$ were an autosomal trait, only one-half of the males of each generation is expected to develop a black gonopodium. This is clearly not the case $(120 \mathrm{Gn}: 49+)$. Only 4 of 19 males of pedigree 1602 were scored as wild-type. If male 1543-11 was homozygous for Gn (either sex-linked or autosomally inherited), about onehalf of the male offspring of pedigree 1717 should have exhibited Gn.

\section{TABLE 2}

Inheritance of black gonopodium (Gn) in Xiphophorus milleri

\begin{tabular}{|c|c|c|c|c|c|c|}
\hline & & & & & & \\
\hline & Parents* & & 우우 & & $\sigma^{\pi} \sigma^{*}$ & \\
\hline 우우 & రేరే & Offspring & + & Sv & $\mathrm{Gn}_{\mathrm{n}}$ & + \\
\hline $\mathrm{CL}^{2}$ & $1543-11 \mathrm{Gn} \dagger$ & 1602 & 26 & & 15 & 4 \\
\hline $1602-1$ & $\mathrm{CL}^{3} \mathrm{~Sv}$ & 1717 & 37 & 40 & & \\
\hline $\mathrm{CL}^{3}$ & $1602-11 \mathrm{Gn}$ & $1784+$ & 55 & & 54 & 7 \\
\hline $1784-1$ & $1784-11 \mathrm{Gn}$ & 1831 & 17 & & 31 & 1 \\
\hline $1784-3$ & $1784-13 \mathrm{Gn}$ & 1835 & 29 & & 16 & 1 \\
\hline $\mathrm{CL}^{5}$ & $1835-11 \mathrm{Gn}$ & 1902 & 18 & & 16 & 1 \\
\hline $\mathrm{Cl}^{6}$ & $1902-11 \mathrm{Gn}$ & 1983 & 10 & & 9 & 6 \\
\hline $\mathrm{Cl}^{6}$ & $1902-12 \mathrm{Gn}$ & 1998 & 3 & & 6 & 1 \\
\hline $\mathrm{CL}^{8}$ & $1983-11+\S$ & 2083 & 19 & & 18 & 9 \\
\hline $\mathrm{CL}^{8}$ & $1983-12 \mathrm{Gn}$ & 2121 & 13 & & 10 & 7 \\
\hline GL" 8 & $1983-13 \mathrm{Gn}$ & 2125 & 7 & & 5 & 5 \\
\hline $\mathrm{CL}^{10}$ & $2125-11 \mathrm{Gn}$ & 2260 & 16 & & 8 & 1 \\
\hline GL10 & $2121-11+\|$ & 2289 & & & 1 & 1 \\
\hline GL 11 & $2260-11 \mathrm{Gn}$ & 2337 & 20 & & 4 & 6 \\
\hline GL'11 & $2083-11+\pi$ & 2357 & 15 & & 5 & 6 \\
\hline
\end{tabular}


Instead, none showed the trait. The results, however, are expected if $\mathrm{Gn}$ is Y-linked. Moreover, three phenotypically wild-type males of the Gn line when mated to $\mathrm{CL}$ females gave rise to $\mathrm{Gn}$ offspring indicating that they carried Gn non-expressed.

Particularly pertinent are those crosses that involve rare $\mathrm{Sv}$ females. We assign to them the XY genotype, since when mated to Gn (XY) males, off-

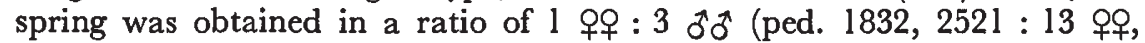
$27 \delta^{7} \chi^{2}=0.68, \mathrm{P}>0.5$; table 3 ). Moreover, with a single exception

\section{TABLE 3}

Inheritance of $S v$ and $G n$ in Xiphophorus milleri (Crosses involving XY females)

Phenotype of Offspring

\begin{tabular}{|c|c|c|c|c|c|c|c|c|c|}
\hline \multirow{2}{*}{\multicolumn{3}{|c|}{ Parents }} & \multirow{3}{*}{$\begin{array}{l}\text { Pedigree of } \\
\text { Offspring }\end{array}$} & \multirow{2}{*}{\multicolumn{2}{|c|}{ 아유 }} & \multirow{2}{*}{\multicolumn{4}{|c|}{00}} \\
\hline & & & & & & & & & \\
\hline कQ⿻ & 00 & & & $\mathrm{~Sv}$ & + & $\mathrm{Sv}$ & SvGn & Gn & + \\
\hline $\mathrm{CL}^{4} \mathrm{~Sv} \mathrm{XY}$ & $1784-12$ & Gn XY & 1832 & - & 4 & 2 & 2 & 2 & - \\
\hline$C L^{5}+X X$ & $1832-11 \mathrm{~Sv}$ & Gn YY & 1891 & 10 & - & 27 & 1 & 25 & 4 \\
\hline $\mathrm{CL}^{12} \mathrm{~Sv} \mathrm{XY}$ & $2337-11$ & Gn XY & 2521 & 1 & 8 & 10 & 5 & 4 & 2 \\
\hline $\mathrm{CL}^{18}+\mathrm{XX}$ & $2521-11 \mathrm{~Sv}$ & Gn YY & 2602 & - & - & 1 & - & - & 1 \\
\hline $\mathrm{CL}^{13}+\mathrm{XX}$ & $2521-12 \mathrm{~Sv}$ & Gn YY & 2660 & - & - & 4 & - & 3 & 2 \\
\hline $\mathrm{CL}^{14}+\mathrm{XX}$ & $2521-13 \mathrm{~Sv}$ & Gn YY & 2669 & 2 & - & 17 & - & 18 & 5 \\
\hline
\end{tabular}

* Superscript refers to inbred generation of CL stock.

females were wild-type (XX) while male offspring consisted of four phenotypic (three genotypic) classes: Sv Gn males have two Y chromosomes, Gn males and presumably the + class in which $G n$ remained unexpressed are $\mathrm{XY}_{\mathrm{Gn}}$, most $\mathrm{Sv}$ males are $\mathrm{XY}_{\mathrm{Sv}}$ but some could have been $\mathrm{YY}$ in which Gn did not manifest itself.

Further evidence for $\mathrm{Y}$-linkage of $\mathrm{Gn}$ and for the XY genotype of the $\mathrm{Sv}$ females is provided by crosses using $\mathrm{Sv}$ Gn males (YY). They sired 49 Sv male offspring $\left(\mathrm{XY}_{\mathrm{Sv}}\right), 46 \mathrm{Gn}$ and $12+$ males $\left(\mathrm{XY}_{\mathrm{Gn}}\right)$ and one $\mathrm{Sv} \mathrm{Gn}$ male (peds. 1891, 2602, 2660, 2669, table 3). The segregation of Sv and $\mathrm{Gn}$ in all but one fish is excellent proof that both $\mathrm{Sv}$ and $\mathrm{Gn}$ are Y-linked. If the Sv Gn male is the product of a cross-over, it would be proof that $\mathrm{Sv}$ and $\mathrm{Gn}$ are not allelic. Unfortunately, this fish was not tested.

No female offspring are expected from YY males; however, there were $12 \mathrm{~Sv}$ females (10 per cent.). Presumably they have the XY genotype and arose by the same unknown mechanism that is responsible for the occurrence of $\mathrm{Sv}$ females in the CL stock. It may be significant that only $\mathrm{Sv}$ females were present in pedigrees 1891 and 2669 while all $\mathrm{XY}_{\mathrm{Gn}}$ fish were males. This suggests that whatever factors are responsible for occurrence of XY females interact with the $\mathrm{Y}$ chromosome marked by $\mathrm{Sv}$ and not with the one marked by Gn.

Since $\mathrm{Gn}$ is Y-linked in our $X$. milleri stock, it cannot be determined whether a similar pattern can develop in the unmodified anal fin of females in the absence of androgenic hormone. Evidence from other species of Xiphophorus suggests that $\mathrm{Gn}$ has no counterpart in females. No black pigmentation has been detected in females of $X$. variatus known to have inherited Gn (see below). Similarly, no pattern equivalent to $\mathrm{Gn}$ has been 
seen in females of preserved collections of $X$. maculatus in which some males exhibit this pattern and in which the $\mathrm{X}$ chromosome is known to be inherited in females. At best the problem can be approached in $X$. milleri by castrating immature males. At the age of 9 months none of four castrates had developed the pattern whereas 10 of 15 controls exhibited $\mathrm{Gn}$ at the age of 4 months and this score increased to 13 of 15 at 6 months (table 4). Three of the castrates received a large amount of methyltestosterone at the age of 9 months. Within 30 days after hormone administration and within 2 weeks after gonopodial transformation was complete, two of the three fish developed $\mathrm{Gn}$ (table 4). Thus, in the absence of male hormone, or alternatively in the absence of the transformed anal fin, $\mathrm{Gn}$ is not expressed in $X$. milleri.

TABLE 4

\begin{tabular}{|c|c|c|c|}
\hline \multicolumn{4}{|c|}{ Hormonal control of the pattern "black gonopodium" in Xiphophorus milleri } \\
\hline No. of fish & Treatment & Age & Results \\
\hline $10 \delta^{*} 0^{*}$ & control & - & $\begin{array}{l}7 \mathrm{Gn} \text { at } 4 \text { months; } 1 \mathrm{Gn} \text { at } 5 \text { months; } 1 \mathrm{Gn} \\
\text { at } 6 \text { months; } 1+\text { at } 18 \text { months }\end{array}$ \\
\hline $5 \sigma^{3} \sigma^{2}$ & sham op. & 5 weeks & $\begin{array}{l}3 \mathrm{Gn} \text { at } 3 \text { months; } 1 \mathrm{Gn} \text { at } 5 \text { months; } 1 \text { tat } \\
9 \text { months }\end{array}$ \\
\hline 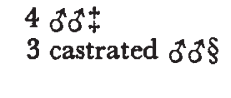 & $\begin{array}{l}\text { castrated } \\
\text { methyl test. }\end{array}$ & $\begin{array}{l}5 \text { weeks } \\
9 \text { months }\end{array}$ & $\begin{array}{l}4+\text { with unmodified anal fin at } 9 \text { months } \S \\
2 \text { Gn } 30 \text { days after treatment } \$ ; 1+68 \text { days } \\
\text { after treatment } \uparrow\end{array}$ \\
\hline
\end{tabular}

* The first brood of pedigree 2260 (listed in table 2) and one fish of second brood (not listed in table 2).

$\dagger$ One fish of second and four fish of third brood.

\#our fish of second brood.

$\S$ These are the same fish; one died at beginning of hormone injection. Hormone administration terminated after eighth injection on 30th day.

|| Gonopodial transformation complete in one fish after 14 days; five injections of $5 \mu \mathrm{l}$ (55 $\mu \mathrm{g}$ m.t.) each.

I Gonopodial transformation complete in two fish after 20 days; six injections of $5 \mu \mathrm{l}$ (25 $\mu$ g m.t.) each.

The expression of $\mathrm{Gn}$ in $X$. milleri is highly variable. It may range from a gonopodium that is entirely black including the specialised distal segments of the 3-5 complex to one in which merely 6-7 large pigment cells were present in the middle of rays 3 or 4 . This latter pigmentation can only be recognised under the microscope. Such fish have been scored as wild-type (e.g. three of four + males of ped. 1602), but presumably even these pigment cells are controlled by Gn, because no such cells have ever been seen, although searched for, in males of the GL stock or in Sv males of pedigree 1717. The area most consistently covered by $\mathrm{Gn}$ is the middle of the shaft (rays 3, 4 and 5) while the immediate proximal and distal portions of the gonopodium (in that order) are black only in the most heavily pigmented fish. In a few isolated cases a dense accumulation of pigment cells was present only at the very base of the fin rays, a pattern that is identical with Gn of $X . v$. variatus (see below). There is no preferential aggregation of pigment cells along the ventral edge of ray 3 as in $X$. v. variatus. In a number of $X$. milleri the darkest pigmentation is found on the "spoon", the troughshaped area that is formed by the distal halves of rays $5 a$ and $p$. Gn in $X$. milleri does not develop until after sexual maturity has been attained. Approximately 70 per cent of the males develop $\mathrm{Gn}$ within 2 months after gonopodial transformation is complete; in the remaining males the pattern 
may not appear until they are 20 months old and in some 2-year-old fish Gn remained unexpressed.

The frequency of $\mathrm{Gn}$ in natural populations of $X$. milleri must be exceedingly low, since this pattern was not represented in the two collections examined (94 mature $\widehat{\partial} \widehat{\partial}, 11$ immature $\widehat{\partial} \widehat{\delta})$.

A correlation has been found in $X$. milleri between the expression of $\mathrm{Gn}$ in a male and its size relative to those of the other males in its group (aquarium). The larger a fish is the more likely it is to express Gn and the more likely its expression will be good. The groups of males (A-N, table 5) are ranked according to the degree of $\mathrm{Gn}$ pigmentation and the standard length of each fish is also given. Since growth rate in fish is notoriously variable and may be influenced by genetic factors, brood size, crowding, light intensity, etc., only those males are included in table 5 that meet the following criteria: (1) all males must be of the same brood; (2) all males were raised together either throughout their entire life-span or since the time when gonopodial transformation began (see methods); (3) all males were sacrificed at the same time or nearly so. This is one of the reasons why the number of males listed for each pedigree in table 5 is less than the numbers for the same pedigree in tables 2 and 3 . A member of a group may also have died or was sacrificed or removed for other reasons before it was measured and scored for the degree of Gn pigmentation. Thirteen of 14 Spearman's Coefficients were positive (table 5). The two-sided probability of this being the case if the two factors were not correlated is only 0.0018 (calculated from a binomial distribution where $\mathbf{P}=0 \cdot 5$ ). The median correlation coefficient of the 14 groups is 0.397 and 95 per cent. confidence limits on the true value give a range of 0.241 to 0.8 (median test). Our interpretation is that there is a weak, but consistent and significant correlation between size and pigmentation of the gonopodium.

Gn males, regardless of whether or not they show the pattern, tend to be larger than Sv (non-Gn) males. A direct comparison of their sizes was possible in one pedigree (2669) in which $\mathrm{Sv}$ and $\mathrm{Gn}$ males were raised together. It should be recalled that when the fish were arranged into the five groups (see methods), Sv and $\mathrm{Gn}$ fish could not be told apart. Thus they are combined randomly. The sizes of the Sv males are listed in footnotes 3-7 of table 5. The difference in size between $\mathrm{Gn}$ (larger) and Sv (smaller) males is statistically significant at the 0.01 level (table 6). The test used, a $\chi^{2}$ analysis of a four-fold table, is conservative and nonparametric.

In pedigree 2602 (table 3 ) only a single brood of two fish was obtained. The Gn male (pattern not expressed) was $25 \mathrm{~mm}$., the Sv male $19.8 \mathrm{~mm}$. Both fish had been raised together throughout the entire life until sacrificed at 9 months.

$\mathrm{Gn}$ and Sv males segregated also in pedigree 2660 (table 3). These fish, however, could not be included in table 6 , because the two classes were neither sibs nor reared together, although raised under similar conditions. The first brood of this pedigree consisted of five fish, all $\mathrm{Gn}$, the second brood of four fish, all Sv. Nevertheless, it is interesting to note that again Gn males tended to be larger (see I, table 5) than those with Sv $(22 \cdot 9,22 \cdot 5$, $22 \cdot 0,18 \cdot 0)$.

For similar reasons the sizes of $\mathrm{Gn}$ and $\mathrm{Sv}$ males of pedigree 1891 could 
not be included in table 6 . This pedigree was made up of four broods, but after sexual maturity had been reached, all males of the first two broods were combined as group A and the fish of the last two broods as group B. Thus, whatever difference in size attributable to their being reared initially in different aquaria is obscured. Nevertheless, the size difference between the two classes of males is quite striking (two-sided, $P=0.0037$, Wilcoxon's $T$ test performed on the combined data; $\left.T_{27,28}=581.5\right)$ and again point to a large median size of $\mathrm{Gn}$ males. The median size of $\mathrm{Sv}$ was $18.9 \mathrm{~mm}$. and of $\mathrm{Gn} 20.6 \mathrm{~mm}$. Thus not a single pedigree or group is known in which the $\mathrm{Sv}$ class is larger in size than the Gn class.

The character black gonopodium of $X$. $v$. variatus is also inherited as a sex-linked trait. The first three crosses listed in table 7 represent fish without the genetic basis for black pigment on the gonopodium. In addition a stock of $X$. v. variatus, VT, also derived from the Rio Tamesi drainage, has been raised in the laboratory for 13 years, but no male ever developed $\mathrm{Gn}$. The two Gn males (2113-11, -12) sired only offspring with clear gonopodia. These results suggests that $\mathrm{Gn}$ may be sex linked and located on the X chromosome. Accordingly, females of pedigrees 2123 and 2387 must carry on one of their X chromosomes Gn. Both pedigrees 2343 and 2250 show this assumption to be correct. Especially telling is the result of pedigree 2343 , because the male parent came from a line from which $\mathrm{Gn}$ was known to be absent.

The results of pedigree 2126 are consistent only with the assumption of $\mathrm{X}$-linkage for $\mathrm{Gn}$. The difference in frequency of $\mathrm{Gn}$ between the sexes (all androgen-treated females were $\mathrm{Gn}$ while only one-half of the adult males exhibited this trait) rules out both autosomal and Y-linkage. It follows that some of the females of pedigree 2126 must be homozygous carriers for $\mathrm{Gn}$, and pedigree 2342 sired by a male of a line known to be free of $\mathrm{Gn}$ illustrates such a case. All X chromosomes of fish of pedigree 2335 and their descendants are marked by $\mathrm{Gn}$ (table 8 ).

The expression of black gonopodium in $X$. $v$. variatus is also highlyvariable. It may range from a condition in which the intense black pigmentation is restricted to the very base of rays 3-7 to one in which also the spoon of ray 5 and the ventral (forward) edge of ray 3 immediately proximal to the spines may be black. In the darkest gonopodia the entire forward edge of ray 3 may be covered with melanophores but the most intense pigmentation is always present adjacent to the spines. The two heavy concentrations of melanophores in the distal part of the gonopodium coincide with the areas where the integument is thickest; during erection both areas come together and form a single black mark facing forwards and upwards, when the distal part of the gonopodium forms a temporary tube.

Even in the gonopodia with the strongest $\mathrm{Gn}$ expression few pigment cells are found between the spoon and the ventral edge of ray 3 and along the middle of rays 3-5. The pattern develops first at the base of the gonopodium and this is also the part of the fin where the pigment cells appear in androgen treated females. The first sign of the pattern may be visible before gonopodial transformation is complete.

\section{Discussion}

The character black gonopodium is represented in four of the eight species of Xiphophorus (Rosen and Kallman, 1969). It is absent from species 


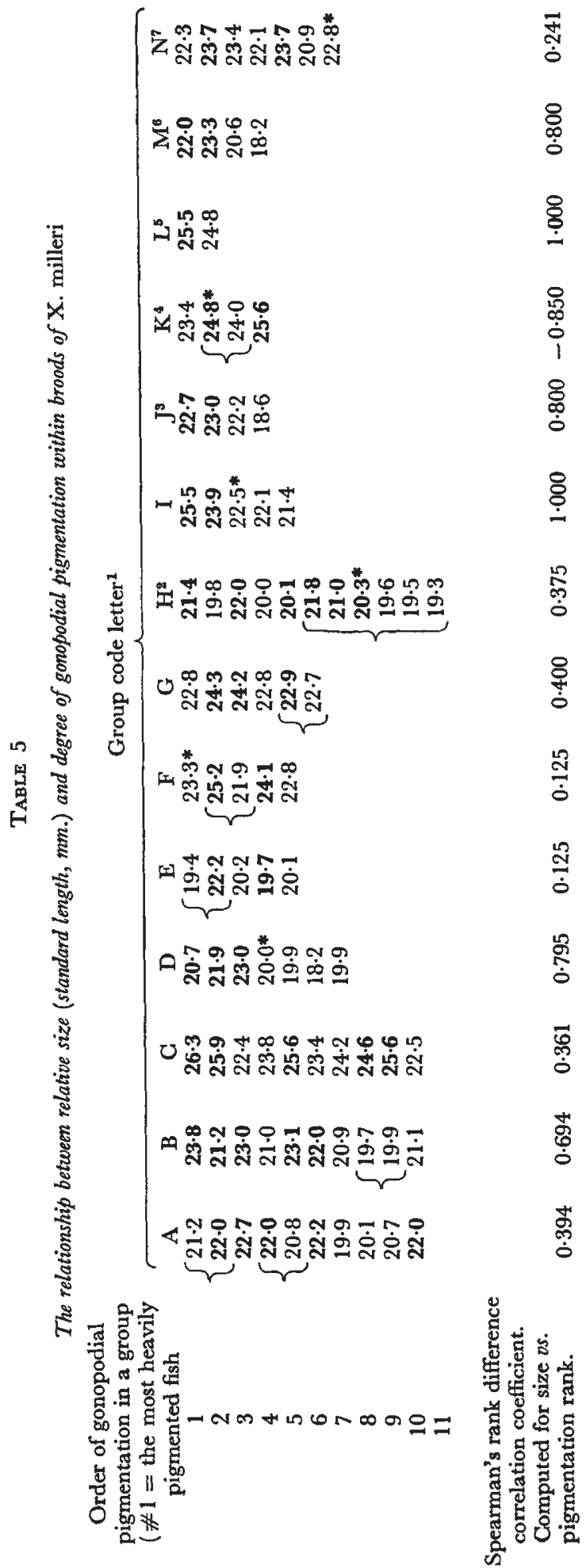




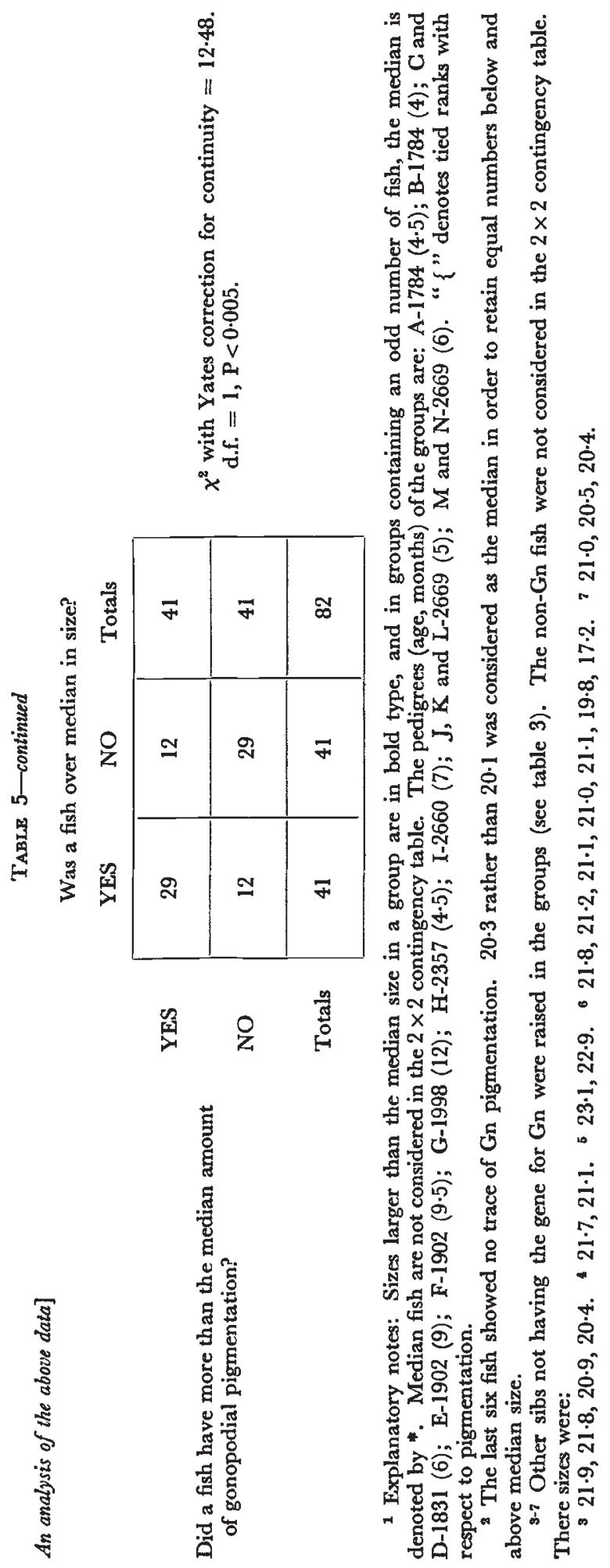


TABLE 6

A comparison of size of Sv and Gn males of X. milleri (ped. 2669)

( $S v$ versus $G n$ males and size above versus below median within $a$ tank*)

Larger than median size in home tank

$\mathrm{Sv}$

Gn

Smaller than median size in home tank

4

15

13

$6 \quad \chi_{1}^{2}$ with Yates' correction is equal to 6.8123 with one degree of freedom. $\mathbf{P}=0.01$.

Since the comparisons are made within the tanks, between tank size difference effects are nullified.

* Their sizes (standard length, mm.) have been listed in table 5 .

TABLE 7

Inheritance of $G n$ in Xiphophorus variatus variatus

\begin{tabular}{|c|c|c|c|c|c|c|c|c|c|c|c|c|c|}
\hline & & & & & & & & & & & & & \\
\hline & ent & d phenotype & & & & 2 & & & & & & & ${ }^{1} \mathrm{C}$ \\
\hline 우와 & & ठव & & Pedigree & 우우 & రై & 우우 & 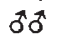 & 우우 & उठ & 우우 & ठवं & 우 ర허 \\
\hline $09-1$ & $P^{2}$ & unknow & & 2110 & 2 & 6 & - & - & - & - & - & - & -1 \\
\hline $0-1$ & $\mathbf{P}^{2}$ & $2110-12$ & $P^{2}$ & $2185 \dagger$ & 16 & 23 & 12 & - & - & - & - & - & -- \\
\hline & + & & & 2 & 9 & 15 & - & - & - & - & - & - & -- \\
\hline & $\mathbf{P}^{2}$ & & 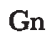 & 2 & 2 & 5 & 43 & - & - & - & - & - & - \\
\hline & + & & & & - & - & 18 & 12 & - & - & - & - & -- \\
\hline & + & & & 234 & - & 4 & 11 & - & - & - & - & 11 & - \\
\hline $2123-2$ & + & 2 & T & 2 & 9 & - & - & 2 & - & 4 & - & - & -- \\
\hline & + & & & & - & - & 50 & 37 & $15 \S$ & 41 & - & - & -- \\
\hline & + & & 1 & & - & - & 16 & - & - & - & - & 13 & -- \\
\hline & + & & 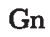 & $23:$ & - & - & 16 & $1 \|$ & - & 14 & - & - & - \\
\hline & + & & & & - & - & 12 & - & - & - & - & - & -17 \\
\hline $2335-1$ & + & $2335-11$ & Gn & 2703 & - & - & 11 & - & - & 13 & - & - & - \\
\hline
\end{tabular}

* Their most likely genotypes are given in table 8 .

$\uparrow 5$ 우, $\mathbf{P}^{2}$ or + , received each a total of $2 \mathrm{mg}$. of testosterone propionate in peanut oil in sixteen $5-\mu 1$ injections over a period of 53 days. No Gn developed. These females served as controls for pedigree 2126 .

$\ddagger$ From 2115 \& $\times 2116$ o.

$\S$ Fifteen 우 were hormone treated, all developed black pigment on modified anal fin. Twelve 우 ( 7 months of age) injected twice with $5 \mu \mathrm{l}(10 \mathrm{mg} . / \mathrm{ml}$.) of methyl testosterone in olive oil. Gn developed on the 9th day after the first injection. Three Pᄋ (5 months of age) received a total of $1.00 \mathrm{mg}$. of testosterone propionate in peanut oil in eight $5-\mu 1$ injections administered over a period of 50 days. Gn developed during the course of this treatment.

|) Fish died when 17 months old.

If From VT stock.

TABLE 8

Probable genotypes of parents listed in table 7

\begin{tabular}{|c|c|c|}
\hline $2109-1$ & $\mathrm{X}_{\mathrm{P}} 2^{2}$ & \\
\hline $2110-1$ & $\mathrm{X}_{\mathbf{P}} 2 \mathrm{X}_{+}$ & $2110-12 X+Y_{P}$ \\
\hline $2185-1$ & $\mathrm{X}_{+} \mathrm{X}_{+}$ & $2185-16 \mathrm{X}_{\mathrm{p}} 2 \mathrm{Y}$ \\
\hline $2111-2$ & $\mathrm{X}_{\mathrm{P}} 2 \mathrm{X}_{+}$ & $2113-11 \mathrm{X}_{\mathrm{Gn}} \mathrm{Y}$ \\
\hline $2151-5$ & $\mathbf{X}_{+} \mathbf{X}_{+}$ & $2113-12 \mathbf{X}_{\mathrm{Gn}} \mathrm{Y}$ \\
\hline $2123-1$ & $\mathrm{X}_{\mathrm{Gn}} \mathrm{X}_{+}$ & $2185-13 X+Y_{P} 2$ \\
\hline $2123-2$ & $\mathrm{X}_{\mathrm{Gn}} \mathrm{X}_{+}$ & $2123-11 \mathrm{X}_{\mathrm{P}} 2 \mathrm{Y}$ \\
\hline $2115-1$ & $\mathrm{X}_{\mathrm{Gn}} \mathrm{X}_{+}$ & $2115-11 \mathrm{X}_{\mathrm{Gn}} \mathrm{Y}$ \\
\hline $2126-7$ & $\mathrm{X}_{\mathrm{Gn}_{\mathrm{n}} \mathrm{X} \mathrm{x}_{\mathrm{n}}}$ & $2185-13 X+Y_{P}$ \\
\hline $2126-5$ & 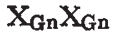 & $2126-11 \mathrm{X}_{\mathrm{Gn}} \mathrm{Y}_{+}$ \\
\hline $2335-2$ & $\mathrm{X}_{\mathrm{Gn}} \mathrm{X}_{\mathrm{Gn}}$ & $2265-11 \mathrm{X}+\mathrm{Y}_{\mathbf{P}}$ \\
\hline $2335-1$ & $\mathrm{X}_{\mathrm{Gn}} \mathrm{X}_{\mathrm{Gn}}$ & $2335-11 \mathrm{X}_{\mathrm{Gn}} \mathrm{Y}$ \\
\hline
\end{tabular}


with moderate to long swords. The trait is quite variable and there is some doubt as to whether the pattern in the different species and subspecies are strictly homologous (i.e. can be traced to a common genetic basis in an ancestral form or to a common developmental mechanism). As far as we know from a cursory survey of preserved collections of $X$. maculatus and $X$. variatus, males with black gonopodia occur in all river systems inhabited by the two species, but the only evidence for the presence of $\mathrm{Gn}$ in $X$. milleri is provided by male 1543-11 (table 2). In contrast to the variation of the three species, all males of Xiphophorus couchianus gordoni exhibit a Gn-like pattern.

The Gn pattern of $X$. variatus and $X$. milleri is presumably made up of macromelanophores sensu Gordon (1926, 1927), because upon close inspection of poorly pigmented gonopodia in which the outline of individual cells can be discerned, the $\mathrm{Gn}$ pigment cells are found to be larger and darker (more pigment) than the perivascular melanophores along the fin rays and those of the "stippled" type (micromelanophores) in the integument. Originally the black pigmentation of the $X$. milleri gonopodium was thought to be composed of micromelanophores (fig. 4, Kallman and Atz, 1966), but this is incorrect. This interpretation was based upon the examination of heavily pigmented gonopodia in which the pigment cells were so tightly packed that their individual shapes and size could not be appreciated. It must be emphasised, however, that no rigid definition of " macromelanophores" and " micromelanophores" exists. The term macromelanophore was first used by Gordon $(1926,1927)$ to describe the large, intensely black pigment cells of the sex-linked pigment patterns of $X$. maculatus. In contrast the term micromelanophores was applied to the smaller integumentary pigment cells that made up the background coloration and certain autosomal pigment patterns. Many-perhaps all-of the macromelanophore factors of $X$. maculatus give rise to atypical pigmentation in certain interspecific crosses while those of the micromelanophore series rarely do so. This definition of macromelanophore, encompassing the criteria of size, sexlinkage and enhancement after hybridisation while useful for $X$. maculatus, breaks down in certain other species of Xiphophorus as already noted by Becker (1965). Gordon (1931) thought that the black phase of the gonopodium of $X$. maculatus was composed of melanophores consisting of the " modified stipple type".

Without exception females of $X$. milleri examined by us (the fish raised in the laboratory and the Michigan collections) possessed a heavy concentration of melanophores on the lower two-thirds of anal fin rays 3, 4 and 5 . A similar pattern is not present in other species of Xiphophorus. These cells are similar in size and intensity of coloration to the stipple cells present in wild-type gonopodia. The black pigmentation in the anal fin of females is presumably a species specific trait and has nothing to do with the polymorphic character. An illustration of a female of $X$. milleri showing this pattern clearly has been published by Kallman and Atz (1966, fig. 4, the female in the upper-left corner). This pigmentation is visible also on the anal fin of the allotype (fig. 8, Rosen, 1960). In the absence of genetic information one could erroneously conclude that this aggregation of pigment cells represent the expression of $\mathrm{Gn}$ in females. If this were the case, however, all females of $X$. milleri would carry this factor and males with $\mathrm{Gn}$ would be expected in the CL line and in the preserved collections. 
The expression of black gonopodium is under the control of androgenic hormone as shown by the hormone experiment with females of $X$. variatus. Thus $\mathrm{Gn}$ has to be considered as a variable secondary sex character which in turn modifies the coloration of another secondary sex character, the gonopodium or male intromittant organ. At least in $X$. variatus the development of the pattern is not contingent upon the structure of a gonopodium. The androgen-treated females do not possess a gonopodium; merely the distal parts of rays 3-5 are somewhat modified. However, in the intact animal the presence of androgenic hormone cannot be separated from the development of a gonopodium. Of the more than three dozen melanophore patterns known in the genus, $\mathrm{Gn}$ is the only one that is under hormonal control: X-linkage of $\mathrm{Gn}$ in $X$. variatus and $\mathrm{Y}$-linkage in $X$. milleri are presumably fortuitous; no claim is made that the $\mathrm{Gn}$ locus of $X$. milleri is restricted to the $\mathrm{Y}$ chromosome. Because of the incomplete penetrance of $\mathrm{Gn}$ in $X$. milleri and its presumed lack of expression in females, cross-overs of $\mathrm{Gn}$ from the $\mathrm{Y}$ to the $\mathrm{X}$ chromosomes are virtually impossible to detect.

A second component of polymorphism affecting the anal fin, Anal-Red, has been described for $X$. maculatus, but no equivalent pattern is known from any other species. The intensity of the coloration of anal red is stronger in males than in females (Valenti, unpublished).

Since several species are polymorphic for $\mathrm{Gn}$, the trait has presumably some adaptive significance. Because of the easily perceived difference between pigmented and unpigmented gonopodia (compare $\mathrm{Sv}+\widehat{\star}, \mathrm{Fig} .4$, with + Gn of, Fig. 5, Kallman and Atz, 1966), this polymorphism may play a role during certain types of behaviour. Unfortunately, no observations have been made on any stock of Xiphophorus with $\mathrm{Gn}$. Fishes of this genus like other poeciliids are known to exhibit "gonopodial swinging " (for references see Franck, 1964), a deliberate flexion and rotation of the gonopodium in conjunction with one of the pelvic fins and accompanied by a peculiar asymmetrical S-curving of the body. The significance of gonopodial swinging is not well understood and no signal function has been ascribed to it. It is performed by isolated males (Clark, Aronson and Gordon, 1954), but its frequency is markedly increased by the presence of females. According to Franck (1964), it is performed in $X$. helleri only when females are present. Yet as various authors have observed gonopodial swinging is neither directed towards the female nor a prerequisite for successful copulation.

The differences in the pigmentation of the gonopodia are least noticeable when they are at rest. To our eyes gonopodial swinging performed by a black gonopodium is a strikingly conspicuous behaviour pattern easily observed over a considerable distance. The same movement by an unpigmented gonopodium is much less pronounced. If this behaviour has a signal function, such a signal could be considerably stronger when reinforced by coloration.

There is a significant trend of decrease in penetrance of Gn correlated with both passage of time and number of back-crosses to the CL stock for which no explanation can be offered. This trend, however, is reversed during the last two back-cross generations. The penetrance of $\mathrm{Gn}$ in pedigree 2669 (from CL11, table 3) is the same as in pedigree 1602 (from $\mathrm{CL}^{1}$, table 2).

Of particular importance, we believe, is the weak yet consistent correla- 
tion in $X$. milleri (but not in the $X$. variatus pedigrees examined) between size of the fish and the intensity of the pattern and the size difference between $\mathrm{Gn}$ and Sv males.

The existence of two size classes within certain pedigrees of $X$. milleri is not a unique phenomenon for the genus. It has long been known to workers in this field (although unfortunately little has been published) that in many forms two types of males (small early maturing ones-_ "low males" and large late-maturing ones-" high males ", in German: Früh- und Spätmännchen.) are found when pure genetic strains are analysed. Since undoubtedly many loci affect size and maturation rate one should not expect to find clear-cut differences in wild populations or heterozygous stocks. Low and high males have been documented in $X$. hellerii (Peters, 1964) and $X$. montezumae cortezi (Zander, 1965) and Rosen and Kallman (1969) have illustrated the two extreme male types of $X$. pygmaeus nigrensis. Anders and Anders (1963) have reported that in $X$. maculatus (derived from the Jamapa population) XY males (heterozygous for $\mathrm{Y}$-linked $\mathrm{Sr}$ ) matured earlier and were smaller than YY males (homozygous for Sr). Many similar examples for $X$. maculatus have been found in our laboratory (Kallman, unpublished). In some instances the difference between the two types of males is of similar magnitude as the one between $\mathrm{Sv}$ and $\mathrm{Gn}$ males of $X$. milleri, but in other pedigrees the two classes are separated by a gap of several millimetres (size) and months (sexual maturity) with no overlap. Without exception the two types of males in pedigrees of $X$. maculatus can always be traced to a sexlinked factor (either X-or Y-linked). Whether the size difference is a pleiotropic effect of a pigment gene which serves as a marker or due to a second locus linked to it is not known. A situation in which different pigment patterns are correlated with adult size and the time of sexual maturation which indirectly affects the behaviour, provides ample opportunity for being maintained as a balanced polymorphism.

\section{Summary}

1. Several species of fishes of the genus Xiphophorus (Poeciliidae) are polymorphic for a black pigment pattern that affects the gonopodium, the male copulatory organ.

2. In $X$. milleri and $X$. v. variatus the pattern is controlled by a sexlinked locus. The gene for black gonopodium, $\mathrm{Gn}$ is $\mathrm{Y}$-linked in the one stock of $X$. milleri examined and $X$-linked in a small sample of $X$. v. variatus from the Rio Tamesi.

3. The expression of $\mathrm{Gn}$ is quite variable and shows less than 100 per cent. penetrance in $X$. milleri. Females of $X$. v. variatus that carry $\mathrm{Gn}$ exhibit a clear anal fin. The pattern can be induced in them by the administration of androgenic hormone.

4. Gn has to be considered a variable secondary sex character which in turn modifies the coloration of another male secondary sex character, the gonopodium.

5. A correlation has been found in $X$. milleri between the expression of $\mathrm{Gn}$ in a male and its size relative to those of other males in its group. The larger a fish is the more likely it is to express $\mathrm{Gn}$ and the more likely its expression will be good.

6. Gn males regardless of whether or not they show the pattern tend to be larger than $\mathrm{Sv}$ (non-Gn) males. 
Acknowledgments.-The research in the Genetics Laboratory is supported by grant RO 1 CA 06665 of the National Cancer Institute, U.S. Public Health Service, which is gratefully acknowledged. Some parts of this paper were taken from a dissertation by Dr Borowsky submitted in partial fulfilment of the requirements for the degree of Doctor of Philosophy at Yale University.

\section{References}

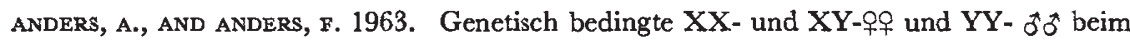
wilden Platypoecilus maculatus aus Mexico. Z. Vererbungsl., 94, 1-18.

BECKER, c. 1965. Untersuchungen zur Phänogenese von Melanophorenmustern bei Zahnkarpfen. Z.F. wiss Zool., 172, 37-103.

BOROWSKY, R. 1969. Ecological and social factors influencing the polymorphic pigmentation systems of Xiphophorus v. variatus (Pisces; Poeciliidae). Ph.D. Thesis, Dept. Biology, Yale University.

CLARK, E., ARONSON, L. R., AND GORDON, M. 1954. Mating behavior patterns in two sympatric species of xiphophorin fishes: Their inheritance and significance in sexual isolation. Bull. Amer. Mus. Nat. Hist., 95, 135-226.

DARNELL, R. M. 1962. Fishes of the Rio Tamesi and related coastal lagoons in east-central Mexico. Publ. Inst. Mar. Sci. Univ. Tex., 8, 299-365.

FRANGK, D. 1964. Vergleichende Verhaltensstudien an lebendgebärenden Zahnkarpfen der Gattung Xiphophorus. Zool. Fb. Physiol., 71, 117-170.

GoRdon, M. 1926. Melanophores of Platypoecilus, the top-minnow of geneticists. Anat. Rec., 34, 138-139.

GORDON, M. 1927. The genetics of a viviparous top minnow Platypoecilus; the inheritance of two kinds of melanophores. Genetics, 12, 253-283.

GORDON, M. 1931. Morphology of the heritable color patterns in the Mexican killifish Platypoecilus. Amer. F. Cancer, 15, 732-787.

GORDON, M., AND ROSEN, D. E. 1951. Genetics of species differences in the morphology of the male genitalia of xiphophorin fishes. Bull. Amer. Mus. Nat. Hist., 95, 409-464.

GROBSTEIN, c. 1948. Optimal gonopodial morphogenesis in Platypoecilus maculatus with constant dosage of methyl testosterone. F. exp. Zool., 109, 215-237.

KALlman, K. D. 1965a. Genetics and geography of sex determination in the poeciliid fish, Xiphophorus maculatus. Zoologica, 50, 151-190.

Kallman, K. D. 1965b. Sex determination in the teleost Xiphophorus milleri. Amer. Zool., 5, 246-247.

KALLMAN, K. D. 1968. Evidence for the existence of transformer genes for sex in the teleost Xiphophorus maculatus. Genetics, 60, 811-828.

KALLMAN, K. D. 1970. Sex determination and the restriction of sex-linked pigment patterns to the $\mathrm{X}$ and $\mathrm{Y}$ chromosomes in populations of a poeciliid fish, Xiphophorus maculatus, from the Belize and Sibun rivers of British Honduras. Zoologica, 55, 1-16.

KALLMAN, K. D., AND ATZ, J. w. 1966. Gene and chromosome homology in fishes of the genus Xiphophorus. Zoologica, 51, 107-135.

MILlER, R. R., AND MINCKLEY, W. L. 1963. Xiphophorus gordoni, a new species of platyfish from Coahuila, Mexico. Copeia, 1963, 538-546.

PETERS, G. 1964. Vergleichende Untersuchungen an drei Subspecies von Xiphophorus helleri Heckel (Pisces). Z. zool. Syst. Evolut.-forsch., 2, 185-271.

Rosen, D. E. 1960. Middle-American poeciliid fishes of the genus Xiphophorus. Bull. Florida State Mus., Biol. Sci., 5, 57-242.

ROSEN, D. E., AND GORDON, M. 1953. Functional anatomy and evolution of male genitalia in poeciliid fishes. Zoologica, 38, 1-47.

ROSEN, D. E., AND KALlMAN, K. D. 1969. A new fish of the genus Xiphophorus from Guatemala, with remarks on the taxonomy of endemic forms. Amer. Mus. Novitates, no. 2379, $29 \mathrm{pp}$.

ZANDER, C. D. 1965. Die Geschlechtsbestimmung bei Xiphophorus montezumae cortezi Rosen (Pisces). Z. Vererbungsl., 96, 128-141. 